\title{
10
}

\section{Sustainable supply chain management}

Peter Lund-Thomsen and Lynn Oxborrow

In this chapter, you will be given an overview of the some of the key challenges related to the theory and practice of sustainable supply chain management. After having read the chapter you should be able to:

- Provide a short definition of sustainable supply chain management

- Briefly describe the historical background for the rise of sustainable supply chain management as an important topic in the study of sustainability management

- Discuss some of the main dilemmas related to the practice of sustainable supply chain management, including both social and environmental sustainability

\section{The concept of supply chain management}

In general terms, supply chain management can be defined as 'the management of upstream and downstream relationships with suppliers and customers to deliver superior customer value at less cost to the supply 
chain as a whole' (Christopher 2011: 3). In this context, upstream to downstream represents the predominant flow of materials from their source to finished goods or services at the point of distribution, while information flows in both directions. The discipline of supply chain management therefore incorporates numerous business functions ranging from product design to procurement, facilities management, production, logistics, marketing, finance and distribution. Trends in supply chain management have seen a rapid growth in outsourcing, where organisations commission a third-party supplier to carry out a specific activity; off-shoring, where such activities are undertaken in a different country from the sourcing organisation; and consequently global sourcing, where the supply chain spans different countries (Slack et al. 2013). Together with the growth in consumerism across the globe, these developments have resulted in more supply chain activity, made more complex by its global nature, and consequently with greater opportunity to impact upon social, environmental and economic sustainability issues.

Citing the Danish Council for Corporate Social Responsibility (2010: 5), we can state that sustainable supply chain management is related to the dialogue that companies 'have with their suppliers in order to prevent violations of fundamental human rights and international environmental standards'. To this definition of sustainable supply chain management, we could also add that companies need to ensure that violations of international labour standards and environmental codes do not take place at suppliers' production sites. International labour standards here refer to issues such as securing workers the minimum wage, reasonable working hours and overtime payment, the right to collective bargaining, freedom of association, and health and safety at supplier factories. Environmental codes include managing product stewardship, production and logistics throughout the supply chain to minimise the negative impacts of using energy, materials, water and harmful substances, while reducing emissions and waste.

The emergence of sustainable supply chain management can be traced back to the rise of global supply chains in the 1980s and 1990s, as a response to various technological and socioeconomic developments. First, international trade had been liberalised substantially through various rounds of free trade negotiations in what is today known as the World Trade Organization. Organisations such as the World Bank and 
the International Monetary Fund had also played key roles in convincing developing country governments that they needed to privatise many state companies and deregulate their national economies (Haufler 2001). In turn, this helped multinational companies not only sell their products in developing countries, but also to set up their own factories or source from local supplier firms that could meet their production, price, timing, and delivery requirements (Gereffi 1999). At the same time, labour costs had gone up in the developed world and environmental regulation been tightened in the 1970s and 1980s, making many retailers and supermarkets look for alternative and cheaper sources of supply in developing countries or countries in transition. In addition, the reduction in air-fare prices and the emergence of the Internet facilitated the rapid growth of global supply chains linking dispersed consumers and importers in the developed world with suppliers, contractors and workers in developing countries (Haufler 2001).

\section{Social sustainability in the supply chain}

Our focus in this section will be on the social aspects of sustainable supply chain management-i.e. the question of how the working conditions of those labouring in supplier factories in developing countries may be improved over time. The concern with the social aspects of supply chain management can be traced back to the early 1990s when a series of media exposés highlighted issues of child labour, forced labour, poverty wages, excessive overtime and general exploitation of workers in the supply chains of some of the world's most famous brands such as Nike and Levi's (Greenberg and Knight 2004). These companies mostly specialised in the branding, marketing and distribution of consumer goods through outlet stores in Europe and the US, but sourced from complex networks of suppliers in developing countries (Bair and Palpacuer 2012).

With the growth of global supply chains in the 1990s and early parts of the new millennium, fears were also increasing that an international social and environmental race to the bottom might be occurring. In relation to the social aspects of sustainability, the nightmare scenario was that well-paid, well-regulated jobs with high levels of social security in 
Europe and North America were now outsourced to countries in Latin America, Asia and Africa whose governments might not care about the wellbeing, health and safety of their workforce (Khara and LundThomsen 2012).

These developments sparked concerted campaigns by trade unions, student organisations, media outlets and NGOs (non-governmental organisations) against the exploitation of workers in developing countries in order to produce cheap goods for Western consumers (Bair and Palpacuer 2012). To respond to these allegations-and protect their brand value-many high-profile Western importers started developing so-called corporate codes of conduct, ethical guidelines which specify the social and environmental conditions under which goods and services are to be produced at supplier factories in developing countries. Corporate codes of conduct will typically state that suppliers must employ workers on a regular contract, that workers must be paid the minimum wage and for any overtime work, that no child labour is employed, and a host of other similar criteria. Western importers often 'borrow' these criteria from international labour standards as specified in the conventions of the ILO (International Labour Organization), an agency of the United Nations entrusted with protecting the rights of workers worldwide (Lund-Thomsen 2008).

By 2006, different scientific and policy-oriented studies highlighted that the outcomes of implementing corporate codes of conduct-at bestbrought about mixed results when it came to ensuring that a social race to the bottom did not take place in developing country export industries (Barrientos and Smith 2007). On the one hand, the implementation of corporate codes of conduct appeared to help factory-based workers by ensuring that they were paid the minimum wage, received overtime payment, and that fewer occupational health and safety accidents took place within supplier factories. On the other hand, codes of conduct appeared to make little or no difference when it came to guaranteeing that workers were free to join trade unions or that they could collectively bargain with their employers in order to improve their work conditions. At the same time, many workers were not really covered by codes as they tended to work further upstream in the supply chain. For example, women and child workers would often be employed in semi-formal workshops or labour at home outside the purview of Western multinational companies 
that mainly sought to keep track of work conditions at the level of their first tier suppliers (ETI 2006).

At the same time, the aforementioned academic and policy studies also highlighted that Western multinational companies tended to use purchasing practices and corporate codes of conduct that contradicted one another (Barrientos and Smith 2007). For example, a Western retailer's procurement staff might ask a supplier to reduce its prices or face the risk of losing an order. At the same time, the retailer's sustainability department might ask the same supplier to increase worker's wages or at least ensure that workers were not cheated of the wages that they had rightfully earned (ETI 2006). Moreover, some Western importers were only able to place orders at certain periods of the year in response to changing seasonal demand in the West. This would often result in employment insecurity in developing country export industries where first-tier suppliers tended to hire and fire workers in response to the level of orders that they received from their buyers. Alternatively, suppliers might subcontract work to smaller suppliers whenever orders were available in order to avoid national labour laws stipulating that workers had to be offered more permanent contracts if they laboured in factory settings (Khara and Lund-Thomsen 2012). Finally, international retailers were criticised for placing orders at the last minute, thus compelling their suppliers in developing countries to force their employees into doing excessive overtime work. As a result, the outcome was often that suppliers had to devise innovative, but perhaps also counterproductive, strategies if they were to stay in business. For example, suppliers might instruct their workers in what to tell the social auditors that were employed by Western importers to check work conditions in these factories. For instance, workers might be instructed to say that they received the minimum wage and were paid for their overtime work if they wanted to retain their jobs (Responsible Purchasing 2006).

Examples such as these also highlight the difficulties and complexities inherent in sustainable supply chain management. Often there are trade-offs between commercial and social considerations which are not easily reconciled. At the same time, even well-intended corporate codes of conduct might do more harm than good to workers in instances where they are implemented without due consideration for local social and environmental circumstances (Lund-Thomsen 2008). For instance, 
Western retailers may stipulate that their suppliers are not allowed to employ children as part of the workforce. However, if strictly enforced, suppliers may feel compelled to fire children working in their factories (e.g. garment and shoe factories), leaving these child labourers and their families with even less income than before. This could possibly force children into even worse types of occupation such as prostitution or bonded labour. Such examples illustrate that implementing 'global' ethical guidelines of companies in 'local contexts' often requires considerable knowledge of the context in which the supplier is operating, the ability to handle dilemmas, and the ability to devise concrete, practical solutions to real-life challenges faced upstream in the global supply chain in developing countries (Lund-Thomsen and Lindgreen 2013). We suggest that you as a student try to explore how to handle such dilemmas in Seminars 1-3 below.

\section{Environmentally sustainable supply chain management}

Srivastava (2007: 54-55) defines green supply chain management as 'Integrating environmental thinking into supply-chain management'. Achieving a sustainable supply chain has become a multidisciplinary task, encompassing relationships, networks, channels and partnerships (Srivastava 2007) throughout the sourcing, process and delivery of goods and services to the final consumer.

There is a lack of consensus regarding the key drivers to instituting a sustainable supply chain. These are variously attributed to market forces (Seuring and Muller 2008), customer buying power, such as retail or public sector (Sharma et al. 2010; Preuss 2009), government regulations (Jones et al. 2008) or consumers demanding better environmentally driven products and services, especially those espoused through corporate value statements. Meanwhile, there are also counter-arguments such as linking green products and services to market failure due to the perception of their being too expensive and functionally or aesthetically inferior (Ginsberg and Bloom 2004). 
Sustainable supply chain initiatives can be implemented in two broad ways. Often they are imposed on suppliers, perhaps as a result of legislation, strategic objectives or codes of conduct of powerful brands and retailers. Alternatively, introducing new and innovative sustainability solutions into the supply chain depends on relationships, sharing of information and working to common goals (Vachon and Klassen 2006), and suppliers are more likely to adopt improvements if they have good relationships with the customers who request those improvements. Implementing a successful sustainable supply chain therefore requires marketing and purchasing functions working together (Sharma et al. 2010), senior management buy-in, a supportive organisational culture and inter-functional co-operation (Krause et al. 2009), with a wider set of performance objectives beyond economic measures (Seuring and Muller 2008). Some generic supply chain concepts such as network design, logistics management, waste minimisation and order fulfilment strategies can help to achieve sustainable supply chain management (Liu et al. 2012; Sharma et al. 2010).

Network design determines location choices for key facilities and the way that goods are moved between them, hence impacting upon supply chain sustainability in a number of ways. One of the key arguments regarding the location of manufacture, warehousing and distribution facilities is the local-global argument. Using more local supply as an alternative to offshore outsourcing is controversial, as there are also social costs to changing sourcing decisions, costs are often considered to be prohibitive and in some developed economies the local infrastructure has declined in traditional industries. In the automotive industry, suppliers are often clustered close to the final assembly plant which reduces the transportation impact of just-in-time delivery, an important factor as deliveries can be required every few hours. Meanwhile, in the food industry, build-to-order based on information sharing with local suppliers reduces unsustainable surplus production and food miles-the distance travelled by components and goods within global supply chains. However, Soler et al. (2010) suggest that adding value by using local suppliers is often in conflict with prevailing procurement legislation which hampers the local supply agenda (Preuss 2009) in favour of impartiality. For an alternative discussion about the value of local and more distant supply see Brindley and Oxborrow (2014). 
Distance and network design in turn impact upon logistics-the planning, control and implementation of moving goods and exchanging information throughout the supply chain, or getting the right product, to the right place, at the right time (SBC 2003). The consensus is that transporting goods less often, in larger volume, is more cost effective as well as being less environmentally damaging, but may not complement contemporary supply chain models such as just-in-time and the fulfilment of online orders. The trend for consolidation is increasingly evident in global shipping, with a growing number of super-ships that can carry more freight, use more sustainable power sources and reduce the cost per item shipped (Mangan et al. 2012). However, these huge ships can only operate in the world's largest ports and so consolidation also involves developing hub and spoke models of storage, transport and distribution along the supply chain, to feed the major shipping routes and offload and redistribute goods into local distribution systems. In integrated supply chains, this role is often outsourced to specialist 3PL (third-party logistics) providers able to introduce the latest technology for warehouse and distribution management, as well as helping to identify opportunities for the sharing of resources between compatible clients. A 3PL provider might enable a Christmas gift company and a garden centre chain with different seasonal peaks to share their warehouse facilities, or suppliers to an automotive plant to share transport for just-in-time delivery. Another example would be filling the base of a truck with heavy bottles and cans of beverage to supply the catering trade, and then using space above to 'top stow' light items such as crisps (SBC 2003).

Choice of mode of transport (road, rail, air or sea-freight, etc.), fuelefficient vehicle designs, reducing vehicle emissions and switching to alternative fuels can also help to reduce the environmental impact of logistics-see the IKEA case study in Seminar 3. In spite of all of these efforts, there are still occasions when goods are flown to their destination in order to enhance responsiveness and reduce lead-time for fashion or perishable items, or to compensate for delays that have occurred elsewhere in the supply chain and meet delivery deadlines.

Waste reduction, which includes over-ordering of materials, or overproduction of components and finished goods, requires input from marketing to produce consistent, stable demand (Chan et al. 2012). However, where there is uncertainty, for example because of seasonality or fashion, 
solutions such as close proximity supplier hubs, exchange of personnel with suppliers and shared plans for new product implementation help keep suppliers abreast of market trends, react more responsively and avoid oversupply. However, as is the case with social sustainability, there are often trade-offs or conflicting outcomes between commercial and sustainability objectives or between the various participants. Indeed, sustainability may be an order qualifier, enabling suppliers to compete for business in a given context, but the prevailing order winner, or decisive selection criterion, is often cost (Cousins et al. 2008). Chan et al. (2012) suggest that the cost imperative in a sustainable supply chain should be reflected through lean thinking or waste minimisation, rather than exploitative cost reduction.

The reverse supply chain is a growing phenomenon in sustainable supply, as legislation, cost pressure and shortage of materials make it more viable for all kinds of recycled items to find their way back into the supply chain-sometimes as completely different products-in a phenomenon known as cradle-to-cradle design (Lovins 2008). The reverse supply chain can be defined as collecting and moving goods from their normal end-of-life for the purpose of capturing value from waste, re-use or refurbishment, or managing their disposal (see Mehrmann 2008). The reverse supply chain can encompass the collection of packaging materials for re-use, of materials for integration into new products, or obsolete or surplus products to be disassembled into constituent parts. It can also include reclaiming fuel, water or waste to be recycled or used in energy generation. Some recycled goods, particularly valuable metals, are exported to global manufacturing locations for sorting, reprocessing and reintegration into new products; others, such as clothing, find a second-hand market in developing economies. However, the supply chain for these processes has to be designed, just like any other.

Companies in the supply chain have the ability to conduct their businesses sustainably through consideration of the triple bottom line: financial, environmental and social sustainability. Suppliers and buyers can therefore improve their approaches to sustainability via:

- Reducing $\mathrm{CO}_{2}$ output

- Recycling and effective waste management

- Using renewable resources 
- Selling ethical products such as organic and Fairtrade

- Providing facilities for communities linked to their suppliers and outlets

- Sustainable logistics/reduced movement

- Reducing wasteful production/processing

- Changing consumption values 


\section{suggested seminars}

\section{Seminar 1: Nike and the dilemmas of social sustainability in Sialkot, Pakistan ${ }^{1}$}

Nike is one of the world's most famous sports brands and, in the early 1990s, started sourcing football (soccer) products. From the mid-1990s and onward, Nike sourced all of its footballs from one supplier, Saga Sports, in Pakistan. Football stitching, the most labour-intensive aspect of football manufacturing, was carried out exclusively by hand, and 75\% of all hand-stitched footballs were manufactured by the 390 small and medium-sized manufacturers in the Pakistani town of Sialkot.

However, machine stitching of footballs was invented in China in the late 1990s, and Chinese football manufacturers could produce large volumes of medium-quality training footballs and lower quality promotional footballs, and do it more quickly than their Pakistani counterparts. Nike began to source footballs from China in the early 2000s. Nike was also concerned about the potential risk of having child labour employed in its football supply chain in Pakistan. Whereas footballs in China tended to be stitched inside factories, in Pakistan manufacturers used large networks of subcontractors to outsource the football-stitching process to designated stitching centres in the villages around Sialkot. Workers from nearby homes would gather in the stitching centres, for males or females, where they could stitch footballs within a designated building or controlled space, and where it was possible to monitor the production process for child labour and workers' rights.

In 2006, Nike decided to cut its ties with Saga Sports because of labour rights transgressions and the unauthorised outsourcing of football stitching from stitching centres to home workers. Immediately after Saga lost the Nike contract, around 7,000 male and female stitchers lost their source of income as Nike tried to switch its entire sourcing of footballs to

1 This seminar is mostly based on the findings presented in Lund-Thomsen and Coe (2013). 
China. However, Nike soon realised that the Chinese manufacturers were not willing or able to meet Nike's entire demand for hand-stitched balls as they did not possess the technological capability to stitch high-quality, hand-stitched match balls and because higher wages in China made the production of hand-stitched footballs in China financially unviable.

Instead Nike re-entered Sialkot, with a new supplier called Silverstar. Under Nike's new production and CSR (corporate social responsibility) philosophy it was decided that all football stitching had to take part inside the Silverstar factory so that children could not become involved in football stitching. All football stitchers were to be paid the minimum wage, they had to be paid for overtime work, and they would receive a higher wage if they managed to stitch more than four footballs per day, the daily quota required by workers within Nike's production regime. Stitchers were also to be provided with health and social insurance (including pension benefits and compensation in case they were laid off). In addition, the football stitchers inside Silverstar were to receive training in workers' rights and to arrange elections inside the factory where workers could freely elect their own representatives. Finally, monitoring of production and work conditions would be undertaken on a weekly basis by Nike's agent in Pakistan—a sourcing company, Matrix Sourcing.

You are now part of a consultancy team that has been asked to undertake an impact assessment of Nike's new production and CSR approach in the Silverstar factory, identifying how aims are being met and whether there are any unintended consequences of Nike's new policies. As part of the impact assessment you interview Nike's sourcing and CSR personnel, the Silverstar management team, Matrix Sourcing, PILER (Pakistan Institute of Labor and Education Research) and the UK-based labour rights consultancy Just Solutions, and conduct 60 interviews with Silverstar football stitchers, divided equally between those working in factories, stitching centres and at home. These interviews are undertaken in the village homes of individual stitchers with the help of local (Punjabispeaking) interpreters. Undertaking these interviews outside the factory premises enables workers to speak freely without being influenced by their managers.

Your interviews with Nike, Silverstar, Matrix, PILER and Just Solutions indicate that Nike's new production and CSR policy is working as 
intended. However, your own observations at the Silverstar factory and the worker interviews tell a different story:

- You observe 400-500 all-male football workers-and your worker interviews indicate that male relatives do not allow female football stitchers to commute to and work in the factory in case they are sexually harassed. Instead female household members are expected by their male family members to undertake childcare and household chores at home.

- Workers do not appear to be paid the full minimum wage, are not receiving any extra payments for exceeding the target of four footballs per day and they have not all received the full compensation owed to them because the factory is in financial trouble. Some $50-60 \%$ of the original 1,200 male stitchers employed at the factory have been laid off, and since the financial crisis Nike is only sourcing $20-25 \%$ of the target 300,000 footballs per month. In order to stay financially afloat, the Silverstar management has no other option but to cut workers' wages.

- Workers report that their representatives have been elected in a free and fair way, but they lack the authority to help workers if their wages have not been paid in full. The representatives are mostly poor and easily intimidated by Silverstar management. However, as the football stitchers have attended the PILER training on workers' rights under Pakistani labour law and Nike's code of conduct, they are now able to calculate their own wages and have started striking whenever anyone's wages are not paid in full. This causes the Silverstar management to lose thousands of dollars every time production is stopped and workers have now been paid at least some of the money owed to them.

Now answer the following questions:

1. How do Nike's CSR requirements affect workers and households in the football manufacturing industry of Sialkot?

2. What trade-offs are evident in the football manufacturing supply chain?

3. What could companies like Nike do better to balance their commercial needs with the needs of the workers and communities involved in football manufacture? 


\section{Seminar 2: Ten questions to ask footwear and garment companies}

In this seminar, you are asked to make an initial, desk-based assessment of whether an importing company in a developed country is using sustainable supply chain management practices. The toolkit includes ten questions that allow you as a student or learner to find out whether a given importing company, for example, a retailer or a supermarket, is in compliance with ethical procurement policy. Select a company and try to find out whether they live up to Oxfam Australia's ethical procurement policy. The ten questions are summarised below and can be downloaded in full from https://www.oxfam.org.au/explore/workers-rights/ resources-for-students/.

1. Does the company have a supplier code of conduct to guide suppliers through the implementation of human rights for their workers?

2. If the company has a code of conduct, is it publicly available? Is the implementation of the code of conduct being audited by a third party? Is the audit process transparent and reports available?

3. Does the company publish a list of its suppliers and their locations? Oxfam sees this as a way to achieve supply chain transparency so that other groups can check working conditions. Would the company consider doing this?

4. Are core ILO conventions ratified in the countries where the company's suppliers are based? This should give workers the right to freedom of association.

5. Does the company have a good system to audit factory conditions? Some commercial auditing causes concerns, so instead Oxfam Australia recommends that local unions and NGOs are involved in any verification process of factory conditions. Workers should be interviewed away from their place of work, so that they can speak more freely and anonymously, and discuss whether they are being treated fairly.

6. Are production workers paid a living wage, rather than a legal minimum wage? NGOs and trade unions can help companies to determine a living wage standard. 
7. Do the suppliers' workers enjoy freedom of association and the right to collective bargaining? Can workers join a trade union? Workers should be interviewed away from their place of work, so that they can speak more freely and anonymously.

8. Does the company know how many workers have joined a workplace union? How well do workers know their rights? Local unions can often send in representatives to inform workers of their rights.

9. Can workers register a confidential workplace complaint? Are any complaints followed up and resolved in a timely fashion?

10. Do production workers have permanent contracts and job security?

\section{Seminar 3: Resolving the trade-offs between commercial and sustainable supply chains}

The issue of location choice is addressed by IKEA who, working with a group of Polish suppliers, reconfigured their supply chain so that two suppliers assumed a co-ordinating role over 26 others and took on the management of centralised distribution facilities. This meant that the suppliers collectively could make more frequent deliveries of smaller batches, which enhanced stock availability in-store, while also taking advantage of more efficient transportation using the local rail network (Bestlog n.d.). IKEA are also known for reducing transport volume by designing products that take up less space, volume and weight, such as jug-shaped watering cans that stack more easily, or flat-packed furniture to be assembled by the consumer (Mangan et al. 2012).

Activity 1

Research the supply chain management practices of IKEA and their code of conduct (IWay). See Bestlog (n.d.) and Ikea.com for a starting point. Alternatively you can do this exercise with a company of your choice. 


\section{Activity 2}

1. With reference to the case study, complete the following table to contrast the key objectives of commercial and sustainable supply chain management/

2. Identify where there are trade-offs (conflicting priorities) and give examples that illustrate your answer.

3. Discuss how companies like IKEA can manage, overcome or remove such trade-offs to improve the sustainability of their supply chain.

\begin{tabular}{|c|c|c|}
\hline & Commercial supply chain & Sustainable supply chain \\
\hline Skill level & Skilled, specific logistics support & \\
\hline Demand pattern & Relatively stable, predictable & \\
\hline Language & English, commercial & \\
\hline Network design & $\begin{array}{l}\text { Configured to optimise structure } \\
\text { and locations }\end{array}$ & \\
\hline $\begin{array}{l}\text { Strategic } \\
\text { objectives }\end{array}$ & $\begin{array}{l}\text { Maximise profit, reduce cost, } \\
\text { return on investment }\end{array}$ & \\
\hline Technology & $\begin{array}{l}\text { State-of-the-art systems, } \\
\text { information sharing }\end{array}$ & \\
\hline Innovation focus & $\begin{array}{l}\text { Process is focused on } \\
\text { standardised supply chain }\end{array}$ & \\
\hline $\begin{array}{l}\text { Execution } \\
\text { time-frame }\end{array}$ & Varies due to market conditions & \\
\hline Infrastructure & Modern, well-maintained & \\
\hline $\begin{array}{l}\text { Product/service } \\
\text { design }\end{array}$ & Standardisation, modularisation & \\
\hline Stakes & $\begin{array}{l}\text { Customer satisfaction, } \\
\text { profitability }\end{array}$ & \\
\hline Control & Centralised control & \\
\hline
\end{tabular}




\section{Additional teaching material and ideas}

\section{'Where from?' ice-breaker}

This is a way to encourage students to get to know each other and learn more about sustainable supply chains. In pairs or threes, examine labels in the clothes you are wearing, the snacks in your cafeteria or the contents of your bag. Map where each of your items has come from, and then identify any aspects of sustainability that might relate to the items and their supply chains, such as transport, packaging, materials, production processes, waste or recycling, skills, working conditions, etc. The groups can compare notes by presenting their most interesting and surprising 'finds'.

\section{The Buying Game}

The Buying Game is an online game developed by the UK charity Traidcraft and the Chartered Institute of Purchase and Supply. The game helps interested learners to improve their knowledge of the everyday realities faced by farmers, workers and communities in developing countries and the social aspects of sustainable supply chain management, enabling practitioners to improve the way they purchase so that low-income producers and workers can improve their livelihoods and conditions of work. The game asks learners to answer a series of questions about how they would buy an imaginary product called a 'dimble' that is produced in the developing world and sold to consumers in the West. There are six scenarios in which the buyer must make purchasing decisions and identify the consequences-whether positive or negative-further up the supply chain for local producers, workers and communities in developing countries.

The Buying Game is most usefully played in groups of two, each with a laptop. Their experience of having played the game can then be discussed in a plenary setting at the end of the session. The Buying Game can be accessed and played free of charge at www.thebuyinggame.org/ 


\section{Short videos}

If you prefer to watch video material, the following provide a short introduction to environmental sustainability in the supply chain:

- www.greenconduct.com/news/2011/10/23/video-future-supplychain-2016/ features supply chain practitioners from some of the world's leading corporations discussing how they can balance environmental and commercial pressures in their supply chains

- http://greenconduct.com/news/2011/10/23/video-green-supplychain/ illustrates how the supply chain can adopt more environmentally friendly practices, featuring the reverse supply chain of a carpet supplier

As an alternative, this BBC radio feature, recorded on board a Maersk Line super-ship, discusses aspects of global trade, logistics networks, sustainability in shipping technologies and supply chain security: www.bbc.co.uk/ iplayer/episode/p00r3qlt/One_Planet_Sustainability_on_the_High_Seas/.

\section{Case study resources}

The European Platform for Supply Chain Management Best Practice was established by the European Logistics Association to promote supply chain efficiency and sustainability. The website www.elabestlog.org provides numerous case studies covering all aspects of logistics and supply chain improvements in many different industries.

\section{Topics for debate}

The trade-off choices between commercial and sustainable pressures in the supply chain provide fertile territory for class debate. Topics to explore could include:

- Is it possible to have sustainable fast fashion?

- Local or global: evaluate the social and environmental impact of importing fresh food.

- Reverse logistics in the clothing industry: who benefits from exporting second hand clothes from the West to developing economies? 


\section{Further reading}

For an easy-to-read introduction to sustainable supply chain management, we suggest that you read the Danish Council for Corporate Social Responsibility (2010) guidelines, which provide comprehensive guidelines about dealing with suppliers and setting standards.

Alternatively, a practical guide to help you understand the environmental challenges that businesses face in the supply chain is available from the New Zealand Sustainable Business Council (SBC 2003). This identifies a range of environmental issues at all stages of the supply chain and gives examples of business initiatives.

If you are interested in getting an overview of some more recent developments in the field of sustainable supply chain management from an academic and policy-oriented perspective, the article by Lund-Thomsen and Lindgreen (2013) might be of help to you.

If you are interested in knowing more about how to work practically with solutions to ethical dilemmas that arise in the context of sustainable supply chain management, you should have a look at the document Buying Matters, produced by the UK-based NGO Traidcraft (Traidcraft, 2006).

For a case study in alignment between sustainable supply chain management and the marketing function, read Brindley and Oxborrow 2014. The case shows how a university catering department addressed a marketing challenge by redesigning the supply chain.

\section{References}

Bair, J., and F. Palpacuer (2012) 'From Varieties of Capitalism to Varieties of Activism: The Anti Sweatshop Movement in a Comparative Perspective', Social Problems 59.4 (November 2012): 522-43.

Barrientos, S., and S. Smith (2007) 'Do Workers Benefit from Ethical Trade? Assessing Codes of Labour Practice in Global Production Systems', Third World Quarterly 28.4: 713-29.

Bestlog (n.d.) Reconfiguration of the Supply Chain Structure: Ikea Case, www. elabestlog.org/node/272, accessed 15 June 2014. 
Brindley, C., and L. Oxborrow (2014) 'Aligning the Sustainable Supply Chain to Green Marketing Needs: A Case Study’, Industrial Marketing Management 43: 45-55.

Chan, H.K., H. He and W.Y.C. Wang (2012) 'Green Marketing and its Impact on Supply Chain Management in Industrial Markets', Industrial Marketing Management 41.4: 557-62.

Christopher, M. (2011) Logistics and Supply Chain Management (London: FT Prentice Hall).

Cousins, P., R. Lamming, B. Lawson and B. Squire (2008) Strategic Supply Management: Principles, Theories and Practice (London: FT Prentice Hall).

Danish Council for Corporate Social Responsibility (2010) Guidelines for Sustainable Supply Chain Management, http://samfundsansvar.dk/file/319140/ guidelines_for_sustainable_supply_chain_management_februar_2011.pdf, accessed 2 April 2014.

ETI (Ethical Trading Initiative) (2006) ETI Code of Labor Practice: Do Workers Really Benefit? (Brighton, UK: University of Sussex, Institute of Development Studies)

Gereffi, G. (1999) 'International Trade and Industrial Upgrading in the Apparel Commodity Chain', Journal of International Economics 48.1 (June 1999): 37-70.

Ginsberg, J.M., and P.M. Bloom (2004) 'Choosing the Right Green Marketing Strategy’, MIT Sloan Management Review 46.1 (Fall 2004): 79-84.

Greenberg, J., and G. Knight (2004) 'Framing Sweatshops: Nike, Global Production, and the American News Media', Communication and Critical Cultural Studies 1.2 (June 2004): 151-75.

Haufler, V. (2001) A Public Role for the Private Sector. Industry Self-regulation in a Global Economy (Washington, DC: Carnegie Endowment for International Peace).

Hill, T. (2005) Operations Management, 2nd edn (Basingstoke, UK: Palgrave Macmillan)

Jones, P., D. Comfort and D. Hillier (2008) 'Moving Towards Sustainable Food Retailing', International Journal of Retail and Distribution Management 36.12: 995-1001.

Khara, N., and P. Lund-Thomsen (2012) 'Value Chain Restructuring, Work Organization and Labour Outcomes in Football Manufacturing in India', Competition and Change 16.4 (October 2012): 261-80.

Krause, D., S. Vachon and R. Klassen (2009) 'Introduction and Reflection on the Role of Purchasing Management', Journal of Supply Chain Management 45.4: 18-25.

Liu, S., D. Kastriratne and J. Moizer (2012) 'A Hub and Spoke Model for MultiDimensional Integration of Green Marketing and Sustainable Supply Chain Management', Industrial Marketing Management 41: 581-88. 
Lovins, L. Hunter (2008) 'Rethinking Production', in Worldwatch Institute, State of the World 2008: Innovations for a Sustainable Economy (New York: W.W. Norton): 38-40.

Lund-Thomsen, P. (2008) 'The Global Sourcing and Codes of Conduct Debate: Five Myths and Five Recommendations', Development and Change 39.6 (November 2008): 1005-18.

Lund-Thomsen, P., and N.M. Coe (2013) 'Corporate Social Responsibility and Labour Agency: The Case of Nike in Pakistan', Journal of Economic Geography, http://joeg.oxfordjournals.org/content/early/2013/12/16/jeg.lbt041.full. pdf+html, accessed 30 May 2014.

Lund-Thomsen, P., and A. Lindgreen (2013) 'Corporate Social Responsibility in Global Value Chains: Where Are We Now and Where Are We Going?', Journal of Business Ethics, http://link.springer.com/article/10.1007\%2Fs10551-0131796-x\#page-1, accessed 30 May 2014.

Mangan, J., C. Lalwani, T. Butcher and R. Javadpour (2012) Global Logistics and Supply Chain Management, 2nd edn (London: Wiley).

Mehrmann, J. (2008), Reverse Logistics in Supply Chain Management, www.improvementandinnovation.com/features/article/reverse-logisticssupply-chain-management/.

Preuss, L. (2009) 'Addressing sustainable development through public procurement: the case of local government', Supply Chain Management: An International Journal 14.30: 213-23.

SBC (Sustainable Business Council) (2003) Business Guide to a Sustainable Supply Chain: A Practical Guide, www.sbc.org.nz/resources-and-tools/guides/ sustainable-supply-chain.

Seuring, S., and M. Muller (2008) 'Core Issues in Sustainable Supply Chain Management: A Delphi Study’, Business Strategy and the Environment 17: 455-66.

Sharma, A., G.R. Iyer, A. Mehrotra and R. Krishnan (2010) 'Sustainability and Business-to-Business Marketing: A Framework and Implications’, Industrial Marketing Management 39: 330-41.

Slack, N., A. Brandon-Jones and R. Johnston (2013) Operations Management (Harlow, UK: Pearson).

Soler, C., K. Bergstrom and H. Shanahan (2010) 'Green Supply Chains and the Missing Link between Environmental Information and Practice', Business Strategy and the Environment 19.1: 14-25.

Srivastava, S.K. (2007) 'Green Supply Chain Management: A State of the Art Literature Review', International Journal of Management Reviews 9.10: 53-80.

Traidcraft (2006) Buying Matters-Consultation: Sourcing Fairly From Developing Countries (London: Traidcraft).

Vachon, S., and R. Klassen (2006) 'Extending Green Practices Across the Supply Chain', International Journal for Operations and Production Management 26.7: 795-821. 